\title{
A (des)legitimação do Funk Gospel em blogs evangélicos
}

\author{
Graziela Rocha Reghini Ramos \\ Universidade Estadual de Campinas (UNICAMP), Campinas, São Paulo, Brasil \\ graziela.ramos@gmail.com.br \\ http://orcid.org/0000-0001-8312-0187
}

\section{DOI: http://dx.doi.org/10.21165/el.v47i1.1949}

\begin{abstract}
Resumo
Este trabalho tem como objetivo principal analisar textos argumentativos sobre o funk gospel publicados em dois blogs por diferentes pastores - um representante da Igreja Cristã da Aliança e outro da Assembleia de Deus - e os comentários de seus seguidores, considerando-se, principalmente, como se dá o processo de (des)legitimação de um gênero musical por meio de práticas textuais, ou seja, de que maneira os textos são construídos buscando-se atribuir ao gênero a Macrocategorização Social de ilegítimo por meio de estratégias referenciais. Discute-se ainda o alcance da imposição de determinados valores sociais às práticas musicais.
\end{abstract}

Palavras-chave: categorização; legitimação social; estratégias referenciais; funk gospel.

\section{The (de)legitimation of Funk Gospel in evangelical blogs}

\begin{abstract}
This work has as main objective to analyze argumentative texts about gospel funk published by different pastors in two blogs - one pastor representative of the Igreja Cristã da Aliança and another one of the Assembleia de Deus - and the comments from their followers, mainly considering how the process of (de)legitimation of a music genre happens by means of textual practices, that is, the way these pastors construct their texts in order to reach the Macrocategorization of illegitimate for the genre using the process of reference. It also discusses the reach of the imposition of social values to musical practices.
\end{abstract}

Keywords: categorization; social legitimation; reference; gospel funk.

\section{Introdução}

Os processos de legitimação e deslegitimação de novos gêneros musicais são constantes. Alguns gêneros, inclusive, apesar de já se encontrarem no mercado e terem caído no gosto popular há décadas, ainda enfrentam constantemente lutas para serem reconhecidos como legítimos. É o caso do funk e de suas derivações.

O funk sempre foi visto por muitos críticos como uma forma inferior de cultura. Já na década de 80, época em que desenvolveu sua dissertação de mestrado sobre os bailes funks, Vianna (1987) apontava a dificuldade de se lidar com a heterogeneidade e complexidade das grandes cidades, o que teria levado muitos antropólogos a realizar uma separação entre o que denominaram Cultura e subcultura. $\mathrm{O}$ autor afirma ser o conceito de subcultura apenas uma das maneiras encontradas de simplificação do complexo, uma vez que, ao se declarar a existência de uma subcultura, acredita-se também na existência de uma "totalidade coerente", o que poderia ser chamado de "cultura com C maiúsculo". No entanto, aponta que a cultura em sociedades modernas é um produto de interação e negociação da realidade sempre inacabado, o que faz com que as instituições não expressem consenso, mas apenas um equilíbrio inconstante e precário que precisa ser 
percebido por sua dimensão política de negociação e dominação. Ou seja, inexiste uma cultura que possa ser considerada dominante e universal, capaz de impor seus modos de vida a todo momento, sendo a dominação cultural apenas um produto de um incerto jogo de forças em que vencedores e perdedores podem trocar de posições.

Caracterizando essa disputa entre o que seria efetivamente cultura, Lopes e Facina (2012) apresentam duas justificativas daqueles que desqualificam o funk como gênero musical. Para as autoras, há uma ideia bastante difundida, especialmente por aqueles que se consideram defensores de um certo nacionalismo cultural", que o funk seria um ritmo importado que refletiria "a barbárie das classes subalternas", sendo, portanto, produto de diversas insuficiências, como a de educação, consciência política, de classe, de gosto, de bom senso e até de moral. Outro argumento, considerado por elas como mais nitidamente racista e preconceituoso com a classe social mais baixa, é o de que o funk seria a música dos delinquentes, capaz de incitar a violência e corromper menores, assim como aumentar a utilização de entorpecentes, ou seja, afirmações totalmente moralistas que visam à exclusão do gênero musical e de seus produtores. As autoras apontam que a desqualificação do funk é, na verdade, uma maneira evidente de criminalização da pobreza. $\mathrm{O}$ ataque constante ao funk seria praticado, então, pelo fato de este constituir-se como um gênero representativo do negro e das favelas.

Conforme Bourdieu (2007), qualquer ato de produção cultural resulta na afirmação de busca por legitimidade cultural. Assim, o funk continua perseguindo o seu espaço na cultura brasileira e essas lutas pela (des)legitimação do gênero não têm sido pacíficas. O que se evidencia é que o funk persiste e torna-se mais forte, difundindo-se pelas regiões do país, com diferentes modalidades, e assumindo a cada dia maior importância na sociedade. Uma dessas modalidades é o funk gospel, que se expande cada vez mais, apesar das constantes críticas recebidas. A partir disso, interessa saber como o discurso contrário a ele é construído textualmente e de que forma é reforçado ou contra argumentado por seus receptores. Este trabalho discorre sobre o processo de (des)legitimação de um gênero musical por meio de práticas textuais. Para isso, são analisadas as produções textuais de dois pastores sobre o tema em seus respectivos blogs.

\subsection{Categorização, referenciação e legitimação social}

A legitimação é um fenômeno que ocorre a todo momento em nossa sociedade. Neste trabalho, concordamos com Falcone (2008), para quem as lutas por legitimação realizam-se por meio de práticas sociais e, por isso mesmo, apresentam uma natureza instável, são construídas historicamente e são socialmente contextualizadas. Segundo a autora, não é possível a legitimação ser ditada a partir de uma única instituição, resultando de uma rede de relações sociocognitivas bastante complexa. Ela discute que a (des)legitimação resulta de diferentes atividades sociocognitivas em que ocorrem a categorização de determinados grupos e atores sociais e defende que, por tais grupos se alinharem em um continuum, nenhum deles pode ser em definitivo considerado como legitimado ou deslegitimado, havendo uma tensão constante entre o processo de legitimação e o de deslegitimação.

Falcone (2008) estabelece um interessante paralelo, explicando a legitimação como uma espécie de leitura da sociedade sobre as ações de grupos de atores sociais em um determinado momento histórico, em que tais ações seriam o texto e a categorização como legitimado ou deslegitimado resultaria da ativação de diferentes modelos cognitivos 
construídos a partir da leitura desse texto. Dessa maneira, a autora explica que a legitimação, assim como o texto, não pode ser entendida como um produto acabado, mas sim como um processo concretizado apenas na interação autor-leitor, um vínculo sociointerativo em que os dois são sujeitos na construção de sentidos, já que é na ação da leitura que os sentidos são construídos. A autora reconhece, no entanto, que, apesar dessa tensão constante entre os processos de legitimação e deslegitimação, há discursos que se impõem com o objetivo de impelir outros discursos; porém, se há um movimento de cima para baixo, há também uma resposta de baixo para cima, ou seja, do povo para as instituições, seja como forma de resistir ou de resignar-se.

Apresentando os conceitos de legitimação de Van Dijk, Falcone (2008) afirma que, inevitavelmente, a legitimação encontra-se unida ao processo de afirmação de "Uns" e de negação ou mesmo estereotipização de "Outros". Assim, o processo de legitimação apresenta uma sólida conotação de construção de representações sociais, é orientado de forma ideológica e geralmente encontra-se relacionado a conflitos entre instituições de poder e movimentos sociais, ou seja, a grupos contrários ao status quo, apesar de essa relação não ser estanque, uma vez que mesmo grandes instituições de poder já passaram por "crises de legitimação".

A autora aponta ainda a legitimação como uma Macrocategorização Social. Se a legitimação é uma ação humana, tanto individual quanto coletiva, que ocorre por operações de natureza social e cognitiva que resultam em atividades de categorizações de atores e grupos sociais, essas operações sustentam-se em modelos mentais e representações sociais construídas de forma coletiva sobre tais grupos e participantes. Dessa maneira, nenhum grupo ou ator social pode ser considerado (i)legítimo a priori, já que tal atributo é um ato social, não estanque mas sempre situado, de categorização.

Falcone (2008) acredita que a categorização de grupos e atores sociais como (i)legítimos tem grande importância para as pesquisas sociais, já que dela resultam diferentes ações, como discriminação, preconceito, estereotipização e naturalização de poderes. Para ela, o ato de categorizar é inerente ao ser humano, apesar de não haver uma correspondência direta entre as palavras e as coisas no mundo.

Uma possibilidade de categorização no texto se dá através do processo de referenciação. No entanto, os objetos-de-discurso também não correspondem à realidade extralinguística, conforme afirma Koch (2005). Assim, eles são construídos no processo de interação e a realidade não pode ser construída, mantida ou alterada somente pela maneira como nomeamos o mundo, mas, principalmente, pela forma que interagimos com ele sociocognitivamente.

A referência vai além do estritamente linguístico, abrangendo também o cognitivo e a linguagem usada em contexto e em sociedade, o que leva os processos referenciais a se constituírem como "escolhas do sujeito em função de um querer-dizer" (KOCH, 2005, p. 35). Com isso, a interpretação de uma expressão referencial não se constitui apenas em localizar um antecedente linguístico no texto ou mesmo um objeto específico no mundo, "mas, sim, algum tipo de informação anteriormente alocada na memória discursiva." (KOCH, 2005, p. 35).

Assim, dentro de um texto, é geralmente por meio de estratégias referenciais diversas que categorizamos, o que faz com que os processos referenciais operem diretamente na elaboração do discurso (des)legitimador. Falcone (2008) afirma que a 
referenciação não é apenas um ato de designação e que a construção referencial pode ser considerada como central a todas as ações linguísticas.

No entanto, segundo Silva (2004), ao referir-se a uma interação conversacional, um problema a ser resolvido é justamente a seleção de categorias, uma vez que existem muitas disponíveis. Para a autora, a capacidade de reconhecer e produzir uma forma categorial adequada é "a competência de categorização própria de um membro de um grupo, uma competência sócio comunicacional, permitindo o reconhecimento como parte de uma dada coletividade e a produção de uma conduta reconhecida como adequada ou não, a partir dessas categorias" (SILVA, 2004, p. 175-176).

Com isso, o que se pretende com este trabalho é analisar como as estratégias referenciais contribuem para o movimento de categorização que vai na direção da (des)legitimação do funk gospel, considerando a interação entre dois autores de blogs que discutem o tema com seus leitores comentaristas.

\section{O corpus}

\subsection{Visão geral dos blogs}

Acreditando-se que a referência é sempre situada, depende da relação de interação entre autor e leitor e baseia-se na busca de informações em uma memória discursiva, optou-se por realizar a análise de dois blogs que discorrem sobre o funk gospel, o Blog de Renato Vargens (http://renatovargens.blogspot.com.br) e o Blog do Ciro (http://cirozibordi.blogspot.com.br/), buscando demonstrar como esse gênero musical é caracterizado como ilegítimo de diferentes maneiras pelos autores e por muitos de seus leitores, que constituem-se, em sua maioria, por evangélicos.

É importante salientar que a coleta de dados se deu entre setembro de 2015 e junho de 2017 através de diversos acessos aos blogs e buscas pelo tema funk gospel e que os textos apresentados estão sujeitos a constantes mudanças conforme as atualizações realizadas pelos autores. Isso ocorre porque as produções textuais em blogs são extremamente dinâmicas e, assim como a categorização e a legitimação, estão sempre sendo reconstruídas por seus atores sociais e, portanto, como já indicado, não podem ser entendidas como um produto acabado.

O blog de Renato Vargens informa que se trata de "Um blog com mensagens pastorais e teologia reformada". Na descrição sobre o autor, temos que é um pastor da Igreja Cristã da Aliança que já pregou em diferentes países dos vários continentes e que já publicou 24 livros em português e um em espanhol, além de ser articulista e colunista em diferentes meios de comunicação. Por fim, em sua apresentação, são elencados seus livros publicados e os que ainda estão em produção. Assim, fica evidente a posição de autoridade assumida pelo autor para discutir os assuntos trazidos no blog.

O Blog do Ciro diferencia-se do de Renato Vargens por apresentar mais recursos semióticos que reforçam, o tempo todo, tal autoridade, tais como vídeos, em que muitas vezes a sua imagem se sobressai, estando acompanhado de um microfone, o que enaltece a sua imagem de orador, de alguém que tem o que dizer. Além disso, os pronomes possessivos em frases como "Leia minha coluna no portal CPAD News", "Consulte 
minha agenda", "Conheça as minhas obras", "Meu livro mais recente" e "Meu DVD mais recente" se destacam, fortalecendo a ideia de autoridade.

Em sua autodescrição, Ciro, que é pastor da igreja Assembleia de Deus, ressalta, principalmente, a sua formação e atuação. O autor destaca a sua formação: "Graduações: Teologia (Faculdade Evangélica de São Paulo-SP); Português-Francês (Universidade Federal Fluminense-RJ); Relações Internacionais (Universidade La Salle-RJ).”, sua posição como pastor e professor: "Pastor na Assembleia de Deus da Ilha da Conceição, em Niterói-RJ; pregador do Evangelho, professor de Hermenêutica, Exegese e Teologia Sistemática, autor e articulista."; outras atividades por ele realizadas: "Membro da Academia Evangélica de Letras do Brasil e da Casa de Letras Emílio Conde; colunista do CPAD News; articulista do Mensageiro da Paz (CPAD)"; atividades anteriormente realizadas: "Pastoreou congregações na AD do Ministério do Belém-SP e foi copastor da AD Cordovil-RJ; atuou na CPAD (RJ) como gerente de TI e editor (2001-2008)" e, por fim, os diversos títulos de livros por ele publicados.

Além de todas as caracterizações já indicadas no Blog do Ciro, é interessante apontar que a primeira descrição dada sobre si é a de ser casado e ter uma filha. Isso também é uma forma de chamar a atenção para a importância do discurso produzido pelo autor, uma vez que, para os evangélicos, a família é considerada um dos principais pilares das relações humanas.

\subsection{Os textos dos autores dos blogs}

Os dois blogs têm como objetivo discutir variados assuntos sob a perspectiva religiosa, sendo o funk gospel apenas um dos temas apresentados. Assim, de forma geral, apresentam textos argumentativos que tentam convencer os leitores do que seria considerado certo e do que seria visto como errado segundo critérios religiosos. Há ainda espaço para publicação de comentários dos leitores nas diferentes produções apresentadas.

No blog de Renato Vargens, o tema funk gospel aparece em diferentes momentos, o que pode ser observado através de uma simples busca no blog pela denominação funk gospel. No entanto, há um texto do autor dedicado diretamente ao ritmo, nomeado de "Funk Gospel: O fundo do poço", o qual encontra-se na íntegra abaixo, separado por parágrafos numerados apenas para facilitar a análise no item 4 deste trabalho ${ }^{1}$.

(1) A denominada música gospel me causa arrepios. Confesso que não suporto mais ouvir tanto [sic] bobagem. Se não bastasse isso, eis que surge retumbante neste país tupiniquim o funk gospel. Infelizmente esse ritmo famigerado que tem sido incentivador da promiscuidade e violência nas grandes cidades, agora é evangélico. Para piorar a situação as músicas tocadas além de antropocêntricas, [sic] afrontam o bom senso, disseminando no povo de Deus conceitos antibíblicos e anticristãos. Além disso, as letras são extremamente burrificadas, além obviamente de afrontar o vernáculo.

$$
\text { Veja por exemplo essa “pérola” composta por Adriano Gospel Funk: }
$$

\footnotetext{
${ }^{1}$ Os textos dos blogs não passaram por correção gramatical e/ou ortográfica ao serem transcritos para este trabalho.
} 
Pras irmã e pros irmão

Que curte o som pancadão

Eu mando assim ó:

Vem pro gospel funk

Pra se divertir Com Jesus no coração

Você vai ser feliz então,

vem pro gospel funk

Pra se divertir Com Jesus no coração

Você vai ser feliz então pula e agora dança

A juventude, os adultos, os coroa e as crianças,

então pula e agora dança

A juventude, os adultos, os coroa e as crianças,

então pula e agora dança

A juventude, os adultos, os coroa e as crianças,

A juventude, os adultos, os coroa e as crianças,

Vem pro gospel funk pra se divertir...'

(3) Pois é, confesso que ao ouvir essa coisa horrorosa fui tomado por um pavoroso sentimento de desespero. Francamente, pare, pense e responda: Isto é música? Por favor, seja sincero e responda: Isso significa louvar a Deus? Ah que saudade da boa música, ministrada, cantada, com unção, cuja melodia e letra eram inspiradas pelo Espírito do Senhor.

(4) Definitivamente parece que nos últimos anos, [sic] a igreja de Cristo se perdeu no caminho em direção ao trono do Altíssimo. Sem sombra de dúvidas a coisa está feia!

(5) Que o Senhor nosso Deus tenha misericórdia do seu povo e nos reconduza a sala do trono e que lá possamos adorá-lo integralmente entendendo assim, [sic] que a glória, o louvor, a soberania pertence [sic] exclusivamente a Ele.

(6) Pense nisso!

O blog de Ciro traz o texto "Funk gospel? Conte-me sobre o 'passinho do abençoado" para apresentar o tema. A seguir, encontra-se o texto na íntegra com os parágrafos numerados para auxiliar as análises.

(7) Caro leitor, o que pregadores e ensinadores tementes a Deus e fiéis à sua Palavra, como David Wilkerson, diriam sobre o funk gospel e o "passinho do abençoado"?

Peço-lhe que assista ao vídeo abaixo, leia o artigo subsequente e depois comente sobre o assunto. 
(8) Na sua obra Toca a Trombeta em Sião, publicada em inglês, em 1985 - e lançada no Brasil pela CPAD em 1988 —, David Wilkerson afirmou: "Fiquei extremamente chocado quando recentemente abri uma revista evangélica e vi foto de um grupo de rock 'pesado', dizendo-se evangélico. Estavam vestidos com o mesmo traje sadomasoquista que eu vira antes enquanto testemunhava de [sic] Cristo nas ruas de São Francisco da Califórnia” (p.93).

(9) Wilkerson partiu para a eternidade há um ano, mas a sua mensagem profética ficou registrada: “Onde está a trombeta em Sião, que não toca? Onde está nossa reação? Onde estão os profetas do Senhor que não bradam bem alto: "Chega! A Casa do Senhor não é lugar de música do Diabo!" (p.94).

(10) Como um verdadeiro profeta, Wilkerson verbera contra a covardia dos ministros do nosso tempo: "Que tipo de ministério covarde temos em nossas igrejas de hoje, que tolera e até aplaude um tipo de música que faz os anjos se envergonharem? [...] A música mundana que hoje penetrou na casa de Deus causa repulsa no Céu [...]: 'Como podem pessoas que invocam o santo nome de Cristo apanhar coisas do altar pessoal de Satanás e trazê-las à presença de Deus, lançando-as no seu altar?' [...] Quem são esses roqueiros e inovadores dentro da casa de Deus? São profanadores do santo altar do Senhor!"” (p.95).

(11) Wilkerson condena também a falta de discernimento por parte dos líderes e do povo evangélico, em geral: "O que está acontecendo agora é que pastores e suas igrejas aceitam sem exame, nem discussão, música profana no culto. A voz que se ouve é 'Não julguemos mal', e isso Satanás usa para ocultar todo tipo de males que tal música traz. [...] E é exatamente isto que estes inovadores da música estão fazendo na igreja; destruindo a santidade, zombando da pureza e da separação do mundo" (pp.96-97).

(12) Sem medo, Wilkerson reafirma que a música mundana na igreja é obra do Maligno e verbera contra pais e líderes cristãos por sua conivência: "Satanás está por trás deste tipo de 'louvor' que ele quer que lhe seja prestado. Ele irá até os extremos para corromper o verdadeiro louvor ao Senhor. O inimigo está levando vantagem em sufocar o real louvor em espírito e em verdade. [...] É chocante eu ouvir pais e pastores dizendo-me: 'não julgue desta maneira'. Eles deviam obedecer à Palavra de Deus e julgar segundo a reta justiça, para não perderem seus filhos ante as seduções do mundo" (pp.98-100).

(13) Muitos dizem que a música, seja qual for o estilo adotado, é neutra e que podemos usar todo e qualquer ritmo para o louvor a Deus. Veja a resposta do aludido profeta a esse falacioso pensamento: "Uma das razões por que o Espírito de Deus retirou-se do 'Movimento de Jesus' surgido na década passada [década de 1970] foi que eles se recusaram a largar o tipo de música anticristã que executavam. Eles deixaram as drogas, álcool, prostituição, e até seu modo estranho de vida. Mas não quiseram abandonar o rock. [...] O Espírito de Deus conhece todo mal que há no rock, e Ele nos faz sentir sua tristeza por isso. Os que adoram a Cristo em espírito e em verdade sabem discernir rapidamente o que é o rock" (pp.100-101).

(14) David Wilkerson faz menção também dos [sic] repertórios dos cantores pretensamente evangélicos: "Os roqueiros que se dizem evangélicos costumam ter em suas apresentações e LPs um ou dois hinos realmente sacros, mas o restante é a violenta, selvagem e louca música rock. Significa que se eles quisessem, [sic] podiam fazer a coisa certa e agradável ao Senhor. Certos roqueiros chegam a me dizer: 'Eu mesmo não gosto do rock, mas a juventude gosta, então eu toco rock para atraí-los"” (p.107).

(15) Agora, uma parte bastante antipática — mas verdadeira — da profecia de Wilkerson em relação aos apreciadores de show gospel: "Esse tipo de música copiada do mundo não motiva ninguém a dobrar os joelhos e orar, nem mesmo impulsiona os crentes a curvarem suas cabeças em adoração a Deus. A única coisa que essa música faz é levar o auditório a demonstrações carnais de sacudir o corpo, de bamboleios, de dança, que nada têm de espiritualidade. [...] Deus está dizendo a esta geração que canta e toca música mundana na igreja: 'Rejeitais a música de teus pais que adoravam a Deus com toda pureza. Quereis ver os milagres do livro de Atos, mas não quereis 
a pureza dos vossos pais na fé. Rejeitais a música originada pelo Espírito e abraçais a música que pertence ao mundo"” (p.108-110).

(16) O profeta de Deus geralmente condena o erro e prevê o que acontecerá, caso não haja arrependimento. Veja o que disse Wilkerson, há mais de 25 anos: "Tal música tornar-se-á cada vez mais selvagem, seus festivais de música cada vez mais tenebrosos. Somente crentes desviados, mornos e de nome, frequentarão tais reuniões. Caso o leitor não mais creia em nada do que estou profetizando, creia nisto que vou dizer agora: 'Deus vai fazer uma operação de limpeza na sua casa quanto à música!"” (p.116).

(17) Wilkerson mostra novamente as características da música mundana e, em seguida, conclui: "Já constatei, sem exceção, que todo crente de vida espiritual profunda com Deus e que vive adorando a Deus em espírito e em verdade leva também muito tempo em oração individual. Esse tipo de crente não aceita música frívola, barulhenta ao extremo, acelerada, dissonante. [...] A música mundana na igreja morreria numa semana se cada músico e cantor se humilhasse diante do Senhor e tivesse uma visão do que é a santidade de Deus" (pp.117-118).

(18) Diante do exposto, o que David Wilkerson diria, hoje, a respeito do "passinho do abençoado", do funk gospel e de outras aberrações do nosso tempo?

\section{Análise do corpus}

Algumas considerações podem ser realizadas a partir de (1). Primeiramente, é possível perceber que são conferidas ao gênero diferentes microcategorizações ${ }^{2}$, ou seja, são atribuídos valores durante a coesão referencial que o alocariam na Macrocategoria de ilegítimo. Dessa maneira, o autor do blog retoma "música gospel" tanto como "bobagem" quanto como "ritmo famigerado". Além disso, há a remissão ao funk gospel por meio da qualificação de suas letras como "burrificadas".

Um tom depreciativo é utilizado em referência ao Brasil ("neste país tupiniquim") na tentativa de deixar implícita a possibilidade proporcionada no país de proliferação de gêneros musicais considerados negativos pelo autor.

Aponta-se ainda que o funk seria "incentivador da promiscuidade e violência nas grandes cidades", justamente uma das justificativas expostas por Lopes e Facina (2012) para a criminalização do gênero. Portanto, para Vargens, o funk não deveria ser usado nas igrejas, mesmo que na versão gospel. Nesse momento, fica claro que o autor tem a intenção de recorrer à memória discursiva de seus leitores, que, muitas vezes, já veem o funk tradicional como uma ameaça à sua concepção de Cultura.

Em (2), temos o exemplo de uma música escolhida pelo autor do blog para reforçar a Macrocategorização de ilegítimo para o gênero musical. Antes de apresentá-la, no entanto, Renato Vargens opta por utilizar mais uma microcategorização, "pérola", para referir-se a ela.

É importante observar que o autor faz um recorte ao escolher a música em questão, deixando todas as outras possibilidades de lado. Esse recorte, obviamente, está relacionado à sua intencionalidade, o que se evidencia pelas características do exemplo,

\footnotetext{
${ }^{2} \mathrm{O}$ termo microcategorização é utilizado aqui em relação ao termo Macrocategorização Social, de Falcone (2008). O que se deseja indicar é que a utilização de diversificadas categorizações nos textos dos bloggers contribui para a formação da Macrocategorização Social de ilegítimo para o gênero musical em questão.
} 
já que se trata de apenas uma instrução de dança para divertir-se "com Jesus no coração", repleta de repetições e sem temática aprofundada.

Em (3), a letra apresentada recebe ainda outra microcategorização: "essa coisa horrorosa", demonstrando que o autor não a considera nem mesmo como sendo efetivamente uma música, o que se torna ainda mais evidente quando da utilização do dêitico "Isto" opondo-se à expressão "música" em "Isto é música?". O comentário após a letra da canção traz também uma outra oposição: entre o que é algo ruim (exemplificada através da letra trazida, que não é denominada como música em momento algum) e a "boa música" no trecho: "Ah que saudade da boa música, ministrada, cantada, com unção, cuja melodia e letra eram inspiradas pelo Espírito do Senhor.”.

Em (7), temos o início do texto de Ciro. Com o vocativo "Caro leitor", uma pergunta e um pedido, ele deixa evidente que espera que os que o leem não se restrinjam a tal ação, mas que também participem da postagem através de seus comentários. Já na pergunta inicial, é possível observar que é trazida a citação a uma figura de autoridade, David Wilkerson, famoso evangelista norte-americano, para ratificar a opinião do autor, a qual será referenciada ao longo de todo o texto. Além disso, é utilizado um recurso animado (vídeo) na tentativa de exemplificar e desqualificar o Funk Gospel. O recurso é mobilizado com a dupla função de reforçar a opinião que está sendo apresentada ao mesmo tempo em que invoca e caracteriza o cenário de utilização do funk gospel pelas igrejas.

Em (8), ao trazer a figura de autoridade e uma citação de seu livro, o autor legitima a sua própria opinião fazendo uma analogia entre o que foi dito sobre o rock por David Wilkerson e o que ele pensa sobre o funk gospel. A citação traz ainda a oposição entre Senhor e Diabo e a microcategorização do rock como "música do Diabo" pela figura de autoridade, categorização que pode ser também atribuída ao funk gospel pelo leitor por uma relação de analogia. Ao longo de todo o texto, são citados diferentes trechos do livro da figura de autoridade referindo-se ao rock, sempre como forma de deslegitimá-lo, o que pode levar o leitor a completar a analogia realizada pelo autor, transferindo o que é dito sobre o rock para o funk gospel.

Em (18), a analogia entre o rock e o funk gospel é confirmada na finalização do texto pelo recurso coesivo "Diante do exposto" e uma pergunta sobre o que David Wilkerson, figura de autoridade escolhida para ratificar o que pensa o autor sobre o funk gospel, acharia a respeito da música apresentada no vídeo e o funk gospel, os quais são categorizados como "aberrações" pelo autor, sendo incluídos em uma lista não explicitada através do pronome adjetivo "outras":

\subsection{A interação através dos comentários dos leitores dos blogs}

O texto de Renato Vargens gerou 42 comentários $^{3}$, sendo quatro deles respostas do próprio autor. Como já esperado, por se tratarem de seguidores do blog e também pelo ato enunciativo ser cooperativo, a maior parte é de apoio ao que foi dito e, por tal razão, acrescenta microcategorizações com o objetivo de deslegitimar o ritmo e aqueles que o aceitam, conforme pode ser observado nos exemplos a seguir: "propagadores de heresias", "porcarias", "crentes somente com intenção de ganhar dinheiro", "fracos de

\footnotetext{
${ }^{3}$ Último acesso em 03/06/17.
} 
mente e espíritos", "armas do Diabo", "abominações", "bobagem", "heresias", "besteirol", "lixos", "ritmo agressivo e insuportável”, "fundo do poço", "porcaria carioca", "liquidificador de batidas sem fundamentos".

No entanto, há comentários que também criticam o que foi postado, a maior parte com a colocação de que o importante não é o ritmo, mas sim a letra:

(19) [...] Na minha modesta opinião o rítimo[sic] não quer dizer absolutamente nada o que importa é a letra da música, é claro que uma letra como essa citada passa a ser uma afronta. E a culpa não é de quem faz a música, é de quem põe pra tocar e de quem compra. Eu acho que se chegar um grupo de música evangélica africano com todas as suas vestes tradicionais, instrumentos e danças louvando a Deus de verdade, vai ter gente dizendo que é coisa do diabo sem parar pra dar importância para o que a letra diz.

Um dos opositores chega a apontar o preconceito de forma direta no texto do autor e, mais do que isso, a segregação que é realizada entre os que gostam e os que não gostam de funk:

(20) Nossos preconceitos nos tornam cegos.

Somos só pessoas cheias de ódio.

Procurei na letra algo que levasse a violência e ao sexo e não achei.

Ah, a origem é essa...

Vamos evangelizar pessoas eruditas, que gostam de música de verdade. Quanto aos que gostam de funk, vamos esperar eles abandonarem este estilo, então poderão entrar na nossa igreja.

O autor responde de forma incisiva através de negações à caracterização do funk como música ou arte: "Funk não é música, nem tampouco arte", categoriza ainda o funk como "reverberação da podridão de uma sociedade adoecida", além de fazer referência ao funk como sendo um propagador da "apologia ao crime e promiscuidade".

O texto de Ciro gerou um total de 80 comentários $^{4}$, sendo seis deles respostas do próprio autor. Dos outros 74, apenas cinco são contrários ao que o pastor expõe, o que, de certo modo, já poderia ser esperado pelo fato de os seguidores do blog serem majoritariamente evangélicos.

O primeiro ponto de vista contrário não faz uma defesa ao funk gospel, julgando, inclusive, o vídeo apresentado como "alarmante", porém, argumenta em favor do rock e finaliza com a colocação de que seria possível evitar tais gêneros na igreja para não gerar brigas, mas que em casa seriam bem-vindos de acordo com o gosto pessoal. $\mathrm{O}$ autor do blog responde ao comentário do leitor e lhe sugere um artigo seu para leitura, tentando convencê-lo sobre a inadequação também do rock para os evangélicos.

Já o segundo comentário contrário traz uma argumentação mais ampla, além de criticar o julgamento realizado pelo pastor. Para isso, faz menção direta ao vídeo, afirmando que não havia nele exposição do corpo, sensualidade, palavrões ou adoração a outros deuses, apenas alguém louvando e dançando a Deus. Ciro responde ao comentário,

${ }^{4}$ Último acesso em 03/06/17. 
claramente irritado, e definindo o funk agora como "um estilo erotizante, criado com a intenção de explorar a simulação sexual”.

O terceiro comentário adverso elogia o autor do blog no que se refere à reflexão, mas aponta que pode ser injusto simplesmente rotular os diferentes ritmos através de categorizações como ritmo "sagrado" ou "diabólico". Para tal comentário, Ciro dedica-se a responder utilizando o espaço de quatro comentários, provavelmente por conta da limitação de caracteres. Segue um trecho da resposta do autor:

(21) [...] Assim como não devemos usar drogas, como cocaína ou maconha, para o bem, também não convém usarmos música má, erotizante, entorpecedora, criada para prejudicar as pessoas, levá-las ao delírio (uma espécie de droga audível), para o bem.

\begin{abstract}
Pesquisadores norte-americanos colocaram uma mesma espécie de semente em dois recipientes iguais, com as mesmas condições. Num deles, a planta se desenvolveu muito bem ao som de música clássica. No outro, ao som de heavy metal, não houve o desenvolvimento esperado. Repito: não existe música neutra. Ela é como o alfabeto. Assim como se escrevem mensagens cristãs ou satânicas com as mesmas letras, também se compõem músicas sacras ou demoníacas, com as mesmas notas musicais. Como usar para o bem estilos criados para fins maléficos?
\end{abstract}

Em (21), o autor menciona uma experiência científica realizada com sementes plantadas nas mesmas condições, mas expostas a diferentes tipos de músicas, para afirmar que a neutralidade da música não existe e usa novas categorizações ao comparar alguns gêneros musicais a drogas, capturando no leitor, assim, a memória discursiva de que as drogas são prejudiciais, assim como esses tipos de música. Ao concluir, o autor do blog apresenta mais uma categorização para alguns estilos musicais, qualificando-os como "estilos mundanos e até diabólicos".

Há ainda dois comentários críticos ao autor do blog que não foram respondidos. Um deles questiona o julgamento realizado por Ciro, mas não discute efetivamente a questão do funk gospel dentro das igrejas, apenas critica o uso do gosto pessoal para se julgar a adequação ou inadequação de uma música, ou seja, se um determinado ritmo não agrada, não serve para louvar a Deus. O autor do comentário reclama ainda do fato de Ciro apenas criticar as manifestações contrárias e não responder às manifestações positivas e acusa-o de indicar mais os seus próprios artigos do que "a Palavra do Senhor". O outro comentário discute, assim como nas respostas a Renato Vargens, que o que tornaria a música profana seria sua letra e não seu ritmo e indica dois outros textos para serem lidos pelo autor do blog. Tratam-se dos únicos pontos de vistas negativos sem uma resposta por parte de Ciro.

A grande maioria dos comentários apenas parabeniza o autor pelo texto e reforça o discurso trazido por ele, apresentando novas categorizações não apenas para o ritmo em si, mas também para aqueles que o aceitam, como é possível observar nos exemplos a seguir: "essas abominações musicais", "praga satânica", "essa vergonha", "crentes sem conteúdo bíblico nenhum", "crentes fanáticos", "crentes que defendem mais o cantorídolo do que o evangelho do Senhor", "pessoas que se dizem "crentes", "modismos maléficos", "alguns ditos evangélicos". Essa aceitação e reforço do que é dito justifica-se pelo fato de a grande maioria de leitores dos blogs ser, aparentemente, evangélica e, portanto, tender a seguir o que é dito pelos representantes da religião, no caso, os pastores.

Todos os comentários, positivos ou negativos, demonstram o papel ativo do leitor, que pode, segundo Bentes (2004), agir de maneira mais ou menos cooperativa ao emitir 
julgamentos sobre a coerência ou incoerência da produção textual, levando em consideração suas experiências pessoais, os trechos do texto a que tiveram acesso, os esquemas textuais a partir dos quais a produção se encontra estruturada, ou seja, a atribuição de coerência ou incoerência pode se dar de maneira diferente conforme o leitor.

Nos quadros a seguir, é possível observar uma síntese das microcategorizações utilizadas pelos pastores e por seus comentaristas para o funk gospel e para os seus admiradores como estratégia referencial para atribuir a Macrocategorização de ilegítimo ao ritmo e seus seguidores.

Quadro 1. Microcategorizações utilizadas para of funk gospel

\begin{tabular}{|c|c|c|c|}
\hline & \multicolumn{3}{|c|}{ Microcategorizações } \\
\hline & Renato Vargens & Ciro Sanches Zibordi & Leitores comentaristas \\
\hline $\begin{array}{c}\text { Funk/funk } \\
\text { gospel }\end{array}$ & $\begin{array}{l}\text { - } \text { bobagem; } \\
\text { - } \text { ritmo famigerado; } \\
\text { - } \text { incentivador da } \\
\text { promiscuidade e } \\
\text { violência nas } \\
\text { grandes cidades; } \\
\text { - } \\
\text { sincretismo. } \\
\text { Para a música } \\
\text { trazida como } \\
\text { exemplo: } \\
\text { pérola cultural; } \\
\text { - } \\
\text { coisa horrorosa. }\end{array}$ & $\begin{aligned} &- \text { aberrações. } \\
&- \text { estilos } \\
& \text { impróprios para } \\
& \text { o louvor a Deus; } \\
&- \text { estilos mundanos } \\
& \text { e até diabólicos. } \\
& \\
& \text { Reproduzindo } \\
& \text { David Wilkerson } \\
& \text { sobre o rock e } \\
& \text { relacionando-o } \\
& \text { ao funk gospel: } \\
&- \text { música do Diabo; } \\
&- \text { música profana; } \\
& \text { - } \text { música } \\
& \text { mundana; } \\
& \text { música frívola, } \text { barulhenta ao } \\
& \text { extremo, } \\
& \text { acelerada, } \\
& \text { dissonante. }\end{aligned}$ & 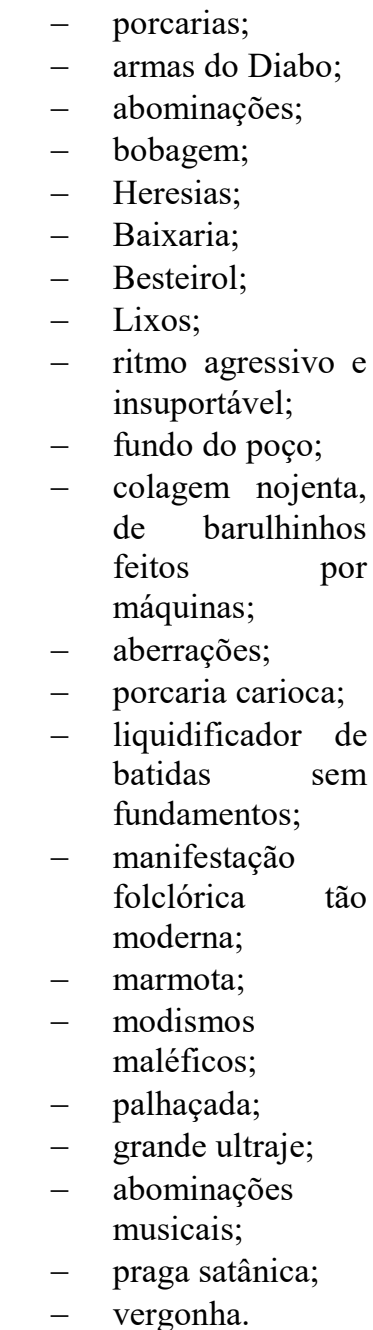 \\
\hline
\end{tabular}

Fonte: Elaboração própria 
Quadro 2. Microcategorizações utilizadas para os admiradores $d o$ funk gospel

\begin{tabular}{|c|c|c|c|}
\hline & \multicolumn{3}{|c|}{ Microcategorizações } \\
\hline & Renato Vargens & Ciro Sanches Zibordi & Leitores comentaristas \\
\hline $\begin{array}{c}\text { Admiradores } \\
\text { do funk } \\
\text { gospel }\end{array}$ & $\begin{array}{c}\text { - Não utiliza } \\
\text { microcategorizações } \\
\text { para se referir aos } \\
\text { admiradores do } \\
\text { funk gospel }\end{array}$ & 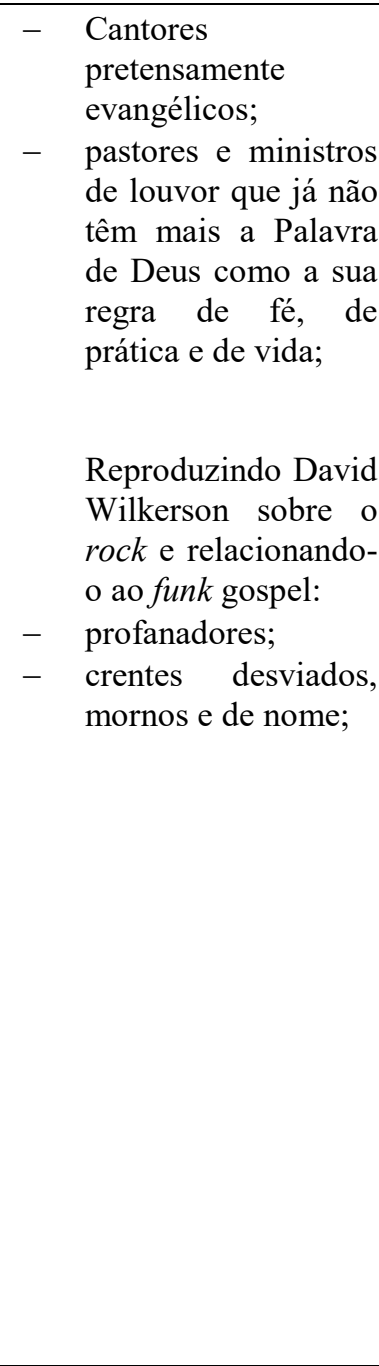 & 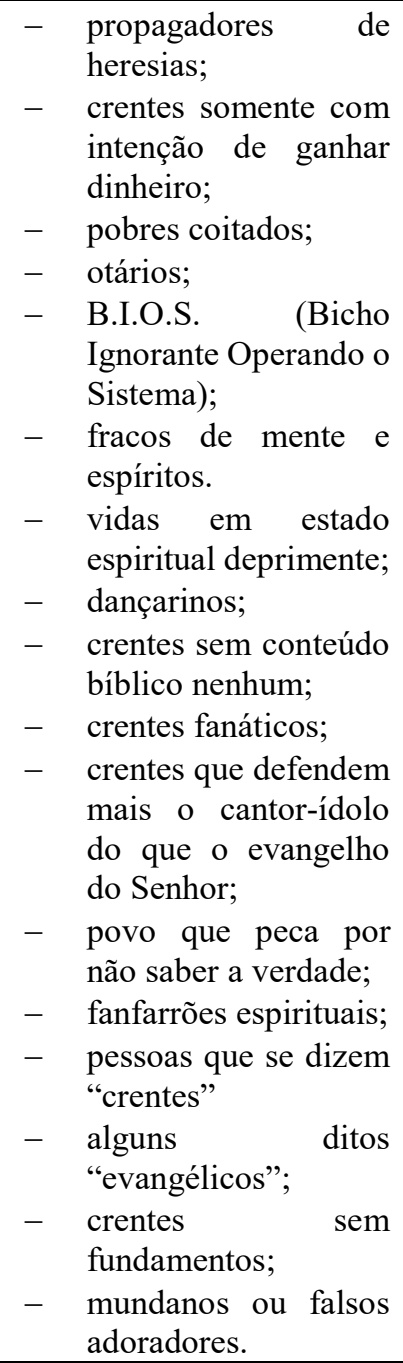 \\
\hline
\end{tabular}

Fonte: Elaboração própria

\subsection{A categorização, o texto e a imposição de valores sociais às práticas musicais nas igrejas evangélicas}

Conforme apontado por Mondada e Dubois (2003), o fato de as descrições do mundo serem incompletas e o de a categorização evoluir de maneira flexível faz com que sua produção seja indissociável do trabalho de interpretação do interlocutor, que as completa e as ajusta ao contexto. Assim, torna-se necessário considerar a criação de uma realidade baseada nas experiências dos indivíduos que convivem e interagem em uma sociedade ou cultura, o que faz com que a recategorização esteja atrelada à significação que se deseja produzir, isto é, aos interesses de enunciação dos interlocutores.

Com isso, as informações partilhadas são abrangentes, mas incompletas, envolvendo todas as crenças, suposições e conhecimentos tanto do emissor quanto do receptor da mensagem. 
Segundo Bourdieu (1987), um texto nada mais é do que o produto de um complexo trabalho histórico de construção de seu agente e constitui-se como a representação que os agentes têm de mundo social e sua construção da visão daquele mundo com a tentativa de imposição de tal visão aos seus leitores. Para ele, na luta simbólica em busca da produção do senso comum (imposição dos valores dos agentes) são utilizados sempre agentes (falantes/escritores) que sejam autorizados (pelos capitais conquistados), ou seja, que reforcem a legitimidade daquilo que está sendo dito. Assim, quanto maiores os capitais conquistados por aqueles que se pronunciam, maiores as possibilidades de imposição de valores. A ideia é retomada pelo autor em 1991, ao discutir especificamente sobre a língua e o seu poder simbólico, ao afirmar que a maioria das condições que têm de ser cumpridas para que uma expressão performática seja bemsucedida se resume à questão da adequação do orador, de sua função social e do discurso que ele pronuncia. Para o autor, um enunciado performativo está destinado a falhar cada vez que não é pronunciado por alguém com poder para isso, isto é, cada vez que o falante não tem autoridade para emitir as palavras que ele pronuncia (BOURDIEU, 1991).

Em nossa análise, isso se torna evidente pela escolha realizada por Ciro ao citar David Wilkerson. Além disso, a imagem dos blogueiros, construída por eles próprios, colocando-se como pessoas habilitadas a se posicionarem sobre os assuntos que se encontram nos blogs contribui para a estratégia de busca do senso comum, o que é ainda reforçado por conta dos recursos semióticos utilizados além dos textos.

Bourdieu (1997) afirma que um dos meios utilizados em lutas políticas se refere à capacidade de imposição de princípios de visão do mundo, em que as pessoas o enxerguem conforme certas divisões (o autor cita os jovens, os velhos, os estrangeiros e os franceses). Segundo ele, a televisão exerce papel determinante quando há a imposição de tais divisões, o que decorre na formação de grupos capazes de se mobilizar e convencer sobre sua existência, fazendo pressão e obtendo vantagens.

Apesar de o autor estar se referindo à televisão, é possível transferir esse papel desempenhado também aos blogs, já que hoje são meios utilizados com o objetivo de impor princípios de visão do mundo, como no caso dos textos analisados em que se busca convencer sobre uma possível oposição entre músicas adequadas e inadequadas para o ambiente da igreja evangélica e entre os que verdadeiramente adorariam a Deus e os que estariam perdidos ao permitirem o funk gospel dentro do ambiente da igreja.

É fato que os mesmos discursos utilizados para deslegitimar o funk apresentados por Lopes e Facina (2012) são trazidos nos blogs também como razões para se desprezar o funk gospel. A verdade, no entanto, como apontado pelas autoras, é que quando o funk ganhou visibilidade, o mesmo aconteceu com os locais em que o gênero era reproduzido, ou seja, as favelas ganharam notoriedade, uma vez que tanto os nomes das músicas quanto dos artistas indicam um referencial comunitário (à Rocinha, Vidigal, Cidade de Deus etc.), o que passou a incomodar muitos estratos da sociedade.

De acordo com Vianna (1987), o divertimento apenas consiste em uma breve fuga das obrigações cotidianas, mas assume papel relevante ao fazer com que cada indivíduo retorne à vie sérieuse com mais coragem e ardor. Assim, "A festa, como ritual religioso, reabastece a sociedade de energia." (VIANNA, 1987, p. 16). O que vemos no caso da utilização do funk gospel pelas instituições religiosas é que há a junção da festa e do ritual, auxiliando os fiéis na difícil tarefa de retornar à "vida séria". Talvez por isso, apesar de todas as críticas, o funk gospel esteja se consolidando também como um espaço de 
resistência permanente no âmbito da igreja evangélica, assim como ocorre com o funk carioca e suas ramificações desde o seu surgimento.

É possível observar nos trechos discutidos que as referenciações e categorizações por meio de anáforas constantes tanto para o funk gospel quanto para aqueles que o apreciam ou o desaprovam atuam o tempo todo como construtores de sentido do texto. Dessa maneira, como coloca Koch (2006), a preferência por determinada descrição pode indicar função avaliativa, ou seja, fazer com que o receptor obtenha informações significativas para a construção do sentido do texto no que se refere às opiniões, crenças e atitudes do emissor.

A intencionalidade é um fator essencial à coerência do texto e os processos de referenciações e categorizações/recategorizações são justamente utilizados com função avaliativa e, principalmente, valor persuasivo, sendo que os autores intencionam construir o sentido de seus textos deslegitimando para o leitor o funk gospel como gênero musical. Mais do que isso, de acordo com Cavalcante (2005), as suposições que o emissor acredita estarem representadas na mente do interlocutor afetam de forma direta as escolhas dos processos referenciais concebidos como mais apropriados aos diferentes momentos de enunciação e os vários modos de expressá-los.

Conforme Bentes (2017, p. 103), os textos atuam como modos de atuação na vida social, "dado que estão repletos de demandas para que compreendamos e aceitemos (ou não) conhecimentos e expectativas socialmente concebidos sobre seus referentes e temáticas e produzamos, também socialmente, sentido(s) sobre (e a partir de) eles.”.

As constantes recategorizações encontradas nos trechos analisados não funcionam, portanto, apenas para reativar referentes previamente apresentados, mas sim contribuem de forma essencial para que o leitor seja levado a compreender e, principalmente, se render à posição contrária dos autores em relação ao gênero musical em questão.

No entanto, torna-se essencial salientar que a recepção do que é dito nunca ocorre de maneira passiva, o que se evidencia pelos comentários realizados pelos leitores, principalmente aqueles que se colocam contrários ao que é dito, havendo, dessa maneira, uma constante interação e ressignificação da mensagem, de acordo com experiências e vivências individuais.

Como já afirmado no início deste trabalho, os processos de legitimação e deslegitimação de gêneros musicais são constantes. Bourdieu (2007, p. 122) coloca:

Por maiores que possam ser as variações da estrutura das relações entre as instâncias de conservação e consagração, a duração do "processo de canonização" (montado por estas instâncias antes de concederem a sua consagração) depende diretamente da medida em que sua autoridade é reconhecida e capaz de impor-se de maneira duradoura. A lei da concorrência pela consagração que exige e confere o poder de consagrar, condena a uma situação de urgência eterna as instâncias de consagração cujo âmbito é mais limitado.

No caso do funk gospel, o que observamos é essa disputa constante dentro das próprias instâncias de consagração, uma vez que, ao mesmo tempo em que temos pastores posicionando-se de maneira totalmente contrária à utilização do funk gospel nas igrejas evangélicas, conforme a análise realizada, temos também diversos outros permitindo e 
até incentivando a sua utilização nas igrejas que comandam, exercendo, assim, um papel forte de legitimação do gênero de maneira direta em seus fiéis.

A dúvida que permanece é sobre como postagens semelhantes às analisadas impactam os consumidores do funk gospel, uma vez que, apesar de todas as campanhas contrárias realizadas por alguns pastores, como os autores dos blogs analisados, e por grande parte de seus leitores, uma simples busca na internet é capaz de indicar diferentes grupos, MCs e DJs representantes do gênero musical, além de reportagens sobre como eles têm sido responsáveis por atrair jovens para as igrejas evangélicas. Assim, é possível dizer que já existe uma indústria do funk gospel, mas há também uma luta incessante com o objetivo de contínua formação da opinião pública por agentes autorizados pela igreja para a sua deslegitimação.

\section{Conclusão}

Neste trabalho, buscou-se demonstrar como o processo referencial, através de microcategorizações, torna-se essencial na busca de uma Macrocategorização de ilegítimo para o gênero musical funk gospel ou para aqueles que o aceitam como prática social nas igrejas evangélicas. Para tal objetivo, analisaram-se as produções textuais de caráter argumentativo sobre o tema de blogs produzidos por dois diferentes pastores e os comentários dos seguidores dos blogs sobre tais textos no que se refere às microcategorizações trabalhadas e também em relação a outras estratégias utilizadas para a tentativa de deslegitimação do funk gospel. Dentre tais estratégias, destacou-se o lugar de autoridade dos emissores, o que representa grande importância em todo o processo. Discutiu-se ainda o quanto o processo de (des)legitimação é complexo e contínuo, além de se realizar a partir das mais diversas práticas sociais.

\section{REFERÊNCIAS}

BENTES. A. C. Linguística textual. In: MUSSALIM, F.; BENTES, A. C. (Orgs.). Introdução à linguística. Domínios e fronteiras. v. 1. 4. ed. São Paulo: Cortez, 2004. p. 245-285.

Temáticas como estratégias discursivas de legitimação social em programas televisivos brasileiros. Letras, Santa Maria, v. 27, n. 54, p. 101-112, jan./jun. 2017.

BOURDIEU, P. 'What Makes a Social Class? On the Theoretical and Practical Existence of Groups'. Berkeley Journal of Sociology, v. 32, p. 1-17, 1987. Data, 1991.

Language \& Symbolic Power. Library of Congress Cataloging-in-Publication

Sobre a Televisão. Rio de Janeiro: Jorge Zahar Ed., 1997.

. A Economia das Trocas Simbólicas. São Paulo: Perspectiva, 2007.

CAVALCANTE, M. M. Anáfora e dêixis: quando as retas se encontram. In: KOCH, I.; MORATO, E.; BENTES, A. C. (Orgs.). Referenciação e Discurso. São Paulo: Contexto, 2005. p. $125-150$. 
FALCONE, K. (Des)legitimação: ações discursivo-cognitivas para o processo de categorização social. 2008. 671 f. Tese (Doutorado em Letras) - Centro de Artes e Comunicação, Universidade Federal de Pernambuco, Recife, 2008.

KOCH, I. V. Referenciação e orientação argumentativa. In: KOCH, I.; MORATO, E.; BENTES, A. C. (Orgs.). Referenciação e Discurso. São Paulo: Contexto, 2005. p. 33-52.

Léxico e progressão referencial. In: RIO-TORTO, G.; SILVA, F.; FIGUEIREDO, O. (Orgs.). Estudos em homenagem ao Professor Doutor Mário Vilela. Porto: Faculdade de Letras da Universidade do Porto, 2006. p. 263-276.

LOPES, A.; FACINA, A. Cidade do funk: expressões da diáspora negra nas favelas cariocas. In: KUSHNIR, B.; HORTA, S. (Edit.). Revista do Arquivo Geral da Cidade do Rio de Janeiro. Rio de Janeiro, n. 6, publicação anual, p. 193-206, 2012.

MONDADA, L.; DUBOIS, D. Construção dos objetos de discurso e categorização: uma abordagem dos processos de referenciação. In: CAVALCANTE, M.; RODRIGUES, B.; CIULLA, A. (Orgs.). Referenciação. São Paulo: Contexto, 2003. p. 17-52.

SILVA, R. M. A. Discurso Científico e Construção Coletiva do Saber: A Dimensão Interativa da Atividade Acadêmico-Científica. 2004. 267 f. Tese (Doutorado em Sociologia) - Centro de Filosofia e Ciências Humanas, Universidade Federal de Pernambuco, Recife, 2004.

VIANNA, H. P. O Baile Funk Carioca: Festas e Estilos de Vida Metropolitanos. 1987. 151 f. Dissertação (Mestrado em Antropologia Social) - Museu Nacional, Universidade Federal do Rio de Janeiro, Rio de Janeiro, 1987.

Recebido em: 30/08/2017

Aprovado em: 02/04/2018 